Prophetic: Professional, Empathy and Islamic Counseling Journal

Vol. 4, No. 1, Juni 2021, hlm. 37-48

e-ISSN : 2685-0702, p-ISSN : 2654-3958

Tersedia Online di http://syekhnurjati.ac.id/jurnal/index.php/prophetic

Email: prophetic@syekhnurjati.ac.id

\title{
Pendekatan Thought Situation Consequences (TSC) Framework untuk Mereduksi Grief
}

\author{
Herny Novianty \\ Program Studi Bimbingan Konseling Islam, Fakultas Ushuluddin Adab dan Dakwah, \\ IAIN Syekh Nurjati Cirebon \\ hernygusbrava@gmail.com
}

\begin{abstract}
This research aimed to know the role of TSC framework for reducing Grief. This study uses a qualitative approach with phenomenological method to explore the experiences and meanings of parents who lost their children in the tragic event of the trial court cases. The sample in this study were parent who lost their children, totally 2 participants. Data was collected by interviewed with openended question. Participant follow 7 stage of counseling of TSC Framework (creating rules, creating perceptions, creating self-talk). The results showed that participant have different reaction to grief, participant didn't go automatically from the situation to the consequence of the situation. The role of TSC Framework in reducing grief can be seen from changing indicator denial, anger, bargaining, depression, dan acceptance. Recommendation showed for Islamic Counseling Guidance study program, and further research.
\end{abstract}

Keywords: Thought Situation Consequences Framework; TSC Framework; Grief.

\section{PENDAHULUAN}

Individu dalam melangsungkan kehidupannya tidak terlepas dari permasalahanpermasalahan yang harus dihadapinya. Pada kenyataannya, tidak semua individu mampu menyelesaikan penyelesaian dengan pemikiran jernih. Dalam hal ini, diperlukan adanya keterampilan monitoring pikiran dan persepsi, Monitoring tersebut erat kaitannya dengan monitoring perasaan dan reaksi fisik. Keterampilan monitoring perlu juga diberikan kepada individu yang mengalami kedukaan mendalam (Grief) pasca ditinggal kematian anaknya.

Holmes \& Rahe menyatakan bahwa ketiadaan anak karena kematian merupakan perubahan hidup yang dapat menimbulkan stres, serta menuntut individu untuk merespon dan melakukan penyesuaian diri. Terkait dengan respon dari stres tersebut, Weiten, Dun, \& Hummer (2019) menyatakan bahwa bentuk respon individu terhadap stres berupa respon emosional berupa rasa duka (grief) dan respon perilaku yang berupa perilaku agresif. Pada 
fase awal individu yang ditinggalkan akan merasa terkejut, bahkan (Santrock, 2004, hlm. 272) merasa tidak percaya dan lumpuh, sering juga ditandai dengan menangis atau mudah marah.

Suatu peristiwa kematian diawali dengan bereavement, yaitu suatu kehilangan karena kematian seseorang yang dirasakan dekat dengan yang sedang berduka dan proses penyesuaian diri kepada kehilangan (Papalia 2008 et al., hlm. 956). Seseorang yang mengalami bereavement wajar apabila mengalami grief. Menurut Papalia et al. (2008) grief adalah respon emosional yang dialami pada fase awal berduka. Dalam hal ini, terjadi kelumpuhan emosional, seperti yang disampaikan Santrock (2004) yang menyatakan bahwa grief merupakan kelumpuhan emosional, tidak percaya, kecemasan, akan berpisah, sedih dan kesepian yang menyertai disaat kehilangan orang yang dicintai.

Hal tersebut dirasakan oleh ibu yang ditinggal kematian oleh anaknya sejak melahirkan di Kabupaten Cirebon. Adapun tahapan-tahapan yang dialami oleh para ibu yang mengalami grief yaitu tahap initial respond, tahap intermediate, tahap recovery. Seperti yang dinyatakan Glick et al. (dalam Lemme, 1995, hlm. 201) membagi tahapan grief menjadi tiga tahap, yaitu sebagai berikut.

a. Tahap Initial Respond

Tahap ini dimulai ketika peristiwa kematian terjadi dan selama masa pemakaman, serta ritual-ritual lain dalam melepas kematian orang yang disayangi. Reaksi awal terhadap kematian orang yang disayangi pada tahap ini meliputi shock atau kaget dan mengalami perasaan tidak percaya. Seseorang yang ditinggalkan akan merasa mati rasa, bingung, merasa kosong, hampa, dan mengalami disorientasi atau tidak dapat menentukan arah.

b. Tahap Intermediate

Tahapan ini adalah lanjutan dari beberapa kondisi pada tahap sebelumnya dan timbul beberapa kondisi baru yang merupakan lanjutan atas reaksi kondisi sebelumnya. Kemarahan, perasaan bersalah, kerinduan, dan perasaan kesepian merupakan emosiemosi yang umum terjadi pada tahapan ini.

c. Tahap Recovery

Pada tahap ini, pola tidur dan makan sudah kembali normal dan orang yang ditinggalkan mulai dapat melihat masa depan, bahkan sudah dapat memulai hubungan yang baru. Pada tahap ini perilaku yang muncul yaitu sudah dapat mengakui kehilangan yang terjadi, berusaha melalui kekacauan yang emosional, menyesuaikan dengan lingkungan tanpa kehadiran orang yang telah tiada dan melepaskan ikatan dengan orang yang telah tiada.

Berdasarkan hasil observasi dan wawancara awal diperoleh informasi dari kepala desa di salah satu kelurahan di Kabupaten Cirebon terdapat warganya yang mengalami hambatan terhadap pemahaman diri, pengarahan diri, serta penghargaan diri setelah ditinggal kematian oleh anaknya. Fenomena tersebut menguatkan bahwa reaksi emosional yang muncul karena 
ditinggal kematian dipengaruhi oleh situasi dan kondisi yang menyertai. Seperti yang diungkapkan oleh Maynasari (2008) dalam penelitiannya bahwa reaksi emosional yang muncul dari ibu yang kehilangan anaknya karena kematian dipengaruhi oleh situasi dan kondisi yang menyertai, kondisi kemelekatan ibu terhadap anaknya, dan harapan orangtua kepada anaknya. Berdasarkan hasil penelitian tersebut, diperoleh bahwa upaya yang dilakukan untuk mengatasi grief yaitu melalui coping (problem focused coping dan emotional focused coping).

Selain itu, menurut De Meij et al. (2005) dalam kedukaan karena kematian anak tidak terlepas juga dari penelurusan penyebab kematian anak yang menjadi prediktor terhadap penyesuaian diri orang tua. Hal tersebut menunjukkan bahwa kematian anak berasosiasi dengan reaksi gejala duka yang lebih intens serta traumatis. Selaras dengan penelitian tersebut, Arnold \& Gemma (2008) menyatakan bahwa kematian merupakan sesuatu yang tak terelakkan dalam hidup, tetapi kematian seorang anak sulit diterima oleh orang tua.

Pada kenyataanya proses duka dapat berbeda-beda pada setiap individu. Kematian anak dapat membuat identitas dan peran individu sebagai orang tua terganggu, serta membuat orang tua kehilangan tujuan hidup jika tidak memiliki keterampilan untuk memonitor pikiran, perasaan, dan tindakannya. Murphy, Johnson, Chung, \& Beaton (2003) dalam penelitiannya menyatakan reaksi duka yang intens akan berkurang seiring berjalannya waktu dengan peningkatan keberfungsian hidup 1.5 tahun setelah kematian anak.

Berdasarkan landasan teoretis dan empiris di atas diperlukan adanya pendekatan Thought Situation Consequences (TSC) Framework untuk mereduksi grief. Pendekatan TSC dalam hal ini yaitu 1) S, Situation (situasi yang dihadapi klien); 2) T, Thoughts (pikiran dan gambaran visual); dan 3) C, Consequences (perasaan, reaksi fisik, komunikasi, dan tindakan). Adapun pendekatan TSC memiliki asumsi bahwa a) konseli tidak pergi otomatis dari situasi (S) ke konsekuensi situasinya; b) konsekuensi (C) dari situasinya (S) dimediasi oleh apa yang dipikirkan dan bagaimana konseli memikirkannya; dan c) perasaan, reaksi fisik, komunikasi, dan tindakan konseli dimediasi secara positif atau negatif oleh pikiran dan proses-proses mentalnya (Nelson-Jones, 2012). Person (2003) dalam pandangannya meyakini bahwa manusia mempunyai keterampilan untuk membangkitkan dan mengakses pikiran.

Pendekatan TSC lebih menekankan pada aspek kognitif, rasional dan behavioral tentang kepribadian, serta berorientasi pada peningkatan kesadaran, sehingga konseli mampu membuat keputusan-keputusan dan rencana baru bagi kehidupannya. Dengan demikian, penelitian ini difokuskan kepada pendekatan TSC framework untuk mereduksi grief.

\section{METODE PENELITIAN}

Penelitian ini menggunakan pendekatan kualitatif dengan metode fenomenologi untuk menggali pengalaman dan pemaknaan orang tua yang kehilangan anak dalam peristiwa tragis persidangan pengadilan kasus. Studi fenomenologi adalah bagian dari pendekatan kualitatif yang berfokus pada pemaknaan individu akan suatu pengalaman (Creswell, 2008). 
Fenomena dalam penelitian ini adalah pengalaman orang tua yang kehilangan anaknya pada tahun 2020.

\section{Partisipan}

Partisipan dalam penelitian ini adalah sepasang orang tua yang kehilangan seorang anak laki-laki di Plered Kabupaten Cirebon, pada tahun 2020. Ayah dari korban berusia 35 tahun, sedangkan ibu korban berusia 27 tahun. Keduanya beragama Islam. Ayah bekerja sebagai pengusaha, sedangkan ibu bekerja sebagai guru. Saat ini, keduanya tinggal di Plered. Partisipan direkrut dengan metode convenience sampling.

\section{Prosedur}

Pengumpulan data dalam penelitian ini dilakukan melalui wawancara dengan pertanyaan terbuka. Partisipan mengikuti 7 tahap sesi konseling dengan waktu 90 menit untuk setiap sesinya sesuai dengan kondisi partisipan. Seluruh sesi wawancara direkam dengan perekam suara untuk ditranskrip verbatim dan dianalisis. Adapun tahapan-tahapan konseling dengan pendekatan TSC Framework sebagai berikut.

\section{Tabel 1. Matrik Pendekatan TSC Framework untuk Mereduksi Grief}

\begin{tabular}{|c|c|c|}
\hline No. & $\begin{array}{l}\text { Tahapan } \\
\text { Layanan }\end{array}$ & $\begin{array}{l}\text { Tahap Inti: Intervensi terdiri dari } 9 \text { sub tahap yang dikelompokkan ke } \\
\text { dalam } 5 \text { sesi }\end{array}$ \\
\hline \multirow[t]{5}{*}{1} & $\begin{array}{l}\text { Sesi } \\
\text { Layanan }\end{array}$ & Sesi 1: Identifikasi Pikiran dan Konsekuensi Di Sebuah Situasi \\
\hline & Waktu & 1x pertemuan (1x 90 menit) \\
\hline & Tujuan & $\begin{array}{l}\text { Konseli dapat mereduksi grief yang berada di fase inisial respon, meliputi } \\
\text { indikator penyangkalan kemarahan, dan tawar menawar. }\end{array}$ \\
\hline & $\begin{array}{l}\text { Deskripsi } \\
\text { Kegiatan }\end{array}$ & $\begin{array}{l}\text { Peneliti mengemukakan tema masalah yang diangkat dari kedukaan kematian } \\
\text { yang dialami, yaitu yang berkaitan dengan sikap menghadapi grief, sehingga } \\
\text { konseli mengangap bahwa permasalahan tersebut merupakan sebuah wadah } \\
\text { yang mewajibkannya untuk belajar menghadapi sebuah masalah. Selanjutnya, } \\
\text { peneliti menyerahkan lembar kerja, memberikan konseling kepada konseli } \\
\text { dan mengkondisikan dengan situasi dimana konseli mengalami perasaan- } \\
\text { perasaan yang membuat distress. Setelah itu, peneliti meminta konseli untuk } \\
\text { mendeskripsikan situasinya, merinci pikiran-pikiran dan gambaran- } \\
\text { gambarannya yang terkait dengan itu, serta mengidentifikasi konsekuensi- } \\
\text { konsekuensi tindakan dari pikiran dan gambaran tersebut. Selanjutnya, } \\
\text { konseli dan peneliti berdiskusi dan bertukar peran. }\end{array}$ \\
\hline & $\begin{array}{l}\text { Penunjang } \\
\text { Teknis dan } \\
\text { Metode } \\
\end{array}$ & $\begin{array}{l}\text { Penunjang teknis: SKLBK, dan jurnal harian kegiatan. } \\
\text { Metode: Diskusi, dan bermain peran. }\end{array}$ \\
\hline \multirow[t]{4}{*}{2} & $\begin{array}{l}\text { Sesi } \\
\text { Layanan }\end{array}$ & $\begin{array}{l}\text { Sesi 2: Membentuk Hipotesis tentang Keterampilan-Keterampilan yang } \\
\text { Diperbaiki }\end{array}$ \\
\hline & Waktu & 1x pertemuan (1x 90 menit) \\
\hline & Tujuan & $\begin{array}{l}\text { Konseli dapat mereduksi grief yang berada fase intermediate, meliputi } \\
\text { indikator penerimaan diri. }\end{array}$ \\
\hline & $\begin{array}{l}\text { Deskripsi } \\
\text { Kegiatan }\end{array}$ & $\begin{array}{l}\text { Konseli yang berperan menjadi pemeran menyusun garis besar adegan yang } \\
\text { dimainkan. Dalam hal ini, peneliti menegaskan pada konseli bahwa dirinya } \\
\text { tidak perlu mempersiapkan dialog khusus. Konseli diminta hanya membuat } \\
\text { sketsa adegan dan perkiraan-perkiraan tindaktinan seorang pemain. } \\
\text { Selanjutnya, peneliti berdiskusi dengan konseli mengenai kebutuhan yang }\end{array}$ \\
\hline
\end{tabular}




\begin{tabular}{|c|c|c|}
\hline & & $\begin{array}{l}\text { diperlukan saat adegan. Berikutnya, peneliti menugaskan pada konseliyang } \\
\text { berperan menjadi pengamat untuk menilai: (1) peran yang dimainkan oleh } \\
\text { pemain apakah sudah sesuai dengan keadaan yang sebenarnya; (2) bagaimana } \\
\text { keefektifan pelaku yang ditunjukkan pemeran; (3) apakah pemeran dapat } \\
\text { menghayati peran yang dimainkan. Setelah itu, peneliti memberikan } \\
\text { kesempatan pada konseliuntuk bertanya perihal pengaturan adegan dan } \\
\text { penugasan. }\end{array}$ \\
\hline & $\begin{array}{l}\text { Penunjang } \\
\text { Teknis dan } \\
\text { Metode } \\
\end{array}$ & $\begin{array}{l}\text { Penunjang teknis: SKLBK, dan jurnal harian kegiatan. } \\
\text { Metode: Diskusi,bermain peran dan penugasan. }\end{array}$ \\
\hline \multirow[t]{5}{*}{3} & $\begin{array}{l}\text { Sesi } \\
\text { Layanan }\end{array}$ & Sesi 4-5: Menciptakan Aturan dan Persepsi \\
\hline & Waktu & 1x pertemuan (1x 90 menit) \\
\hline & Tujuan & Konseli dapat memonitoring pikiran. \\
\hline & $\begin{array}{l}\text { Deskripsi } \\
\text { Kegiatan }\end{array}$ & $\begin{array}{l}\text { Konseli memainkan peran dan menghidupkan situasi secara spontan, dan } \\
\text { saling merespon secara realistis. Dalam hal ini, pemeranan cukup dilakukan } \\
\text { secara singkat, sesuai dengan tingkat kesulitan dan kompleksitas masalah } \\
\text { serta jumlah pemeran yang dilibatkan. Peneliti mengarahkan konseli untuk } \\
\text { menciptakan aturan dan persepsi dengan TSC Framework. Adapun trik khas } \\
\text { pikiran mengikuti apa yang mungkin konseli gunakan di T yang menghasilkan } \\
\text { konsekuensi perasaan, reaksi fisik, dan komunikasi negatif di C: } \\
\text { a) Membuat inferensi yang tidak mendukung. Menarik kesimpulan tanpa } \\
\text { bukti pendukung yang akurat. } \\
\text { b) Menngunakan tunnel vision. Dalam hal ini hanya memfokuskan secara } \\
\text { sempit hanya pada sebagian informasi yang tersedia di dalam situasi yang } \\
\text { tidak mempertimbangkan semua informasi yang signifikan. } \\
\text { c) Berpikir secara hitam putih. Mempersepsi segalanya secara all-or- } \\
\text { nothing. } \\
\text { d) Memperbesar dan meminimalkan informasi relevan. } \\
\text { e) Overgeneralisasi. Membuat komentar-komentar umum yang mungkin } \\
\text { tidak akan dapat didukung oleh konseli jika ia mau berusaha mencek } \\
\text { bukti-buktinya. } \\
\text { f) Bersikap terlalu negatif. Melekatkan label-label negatif dan kritis tanpa } \\
\text { dasar kepada dirinya sendiri maupun ke orang lain. } \\
\text { Selanjutnya peneliti dan konseli melakukan diskusi dan evaluasi mengenai } \\
\text { penafsiran terhadap pemeranan. Berikutnya, peneliti memberikan kesempatan } \\
\text { kepada konseli untuk bertanya mengenai pemeranan. }\end{array}$ \\
\hline & $\begin{array}{l}\text { Penunjang } \\
\text { Teknis dan } \\
\text { Metode }\end{array}$ & $\begin{array}{l}\text { Penunjang teknis: SKLBK, papan tulis, dan spidol. } \\
\text { Metode: bermain peran, dan tanya jawab. }\end{array}$ \\
\hline \multirow[t]{4}{*}{4} & $\begin{array}{l}\text { Sesi } \\
\text { Layanan }\end{array}$ & Sesi 6: Menciptakan Self-Talk \\
\hline & Waktu & 1x pertemuan (1x 90 menit) \\
\hline & Tujuan & Konseli dapat mereduksi grief di fase recovery. \\
\hline & $\begin{array}{l}\text { Deskripsi } \\
\text { Kegiatan }\end{array}$ & $\begin{array}{l}\text { Peneliti menanyakan kepada konseli tentang apa yang terlintas di benaknya } \\
\text { sebelum, selama, dan setelah situasi bermasalah (problem situation) tertentu. } \\
\text { Selanjutnya peneliti mencari self-talk yang meningkatkan kemungkinan } \\
\text { timbulnya perasaan- perasaan yang merugikan dan tindakan yang merugikan } \\
\text { diri sendiri konseli. Selanjutnya, peneliti menugaskan kepada konseli yang }\end{array}$ \\
\hline
\end{tabular}




\begin{tabular}{|c|l|l|}
\hline \multirow{2}{*}{$\begin{array}{l}\text { Penunjang } \\
\text { Teknis dan } \\
\text { Metode }\end{array}$} & $\begin{array}{l}\text { yang berperan menjadi pemain untuk melakukan pemeranan self-talk positif. } \\
\text { Setelah itu peneliti memberikan kesempatan kepada konseli untuk bertanya } \\
\text { perihal pemeranan yang telah dilakukan. }\end{array}$ \\
\hline $\mathbf{5}$ & $\begin{array}{l}\text { Sesi } \\
\text { Layanan }\end{array}$ & Sesi 7: Berbagi Pengalaman dan Pengambilan Kesimpulan \\
\cline { 2 - 3 } & Waktu & 1x pertemuan (1x 90 menit) \\
\hline Tujuan & Konseli dapat mereduksi grief di fase recovery. \\
\hline $\begin{array}{l}\text { Deskripsi } \\
\text { Kegiatan }\end{array}$ & $\begin{array}{l}\text { Peneliti mengajak konseli untuk berdiskusi mengenai berbagai pengalaman } \\
\text { tentang permainan peran yang dilakukan. Hal tersebut dilakukan agar konseli } \\
\text { dapat bercermin pada orang lain untuk lebih memahami dirinya. Selanjutnya } \\
\text { peneliti memberikan kesempatan pada konseli untuk bertanya. Berikutnya } \\
\text { peneliti bersama konseli mengambil kesimpulan dari kegiatan bermain peran. }\end{array}$ \\
\hline & $\begin{array}{l}\text { Penunjang } \\
\text { Teknis dan } \\
\text { Metode }\end{array}$ & $\begin{array}{l}\text { Penunjang teknis: SKLBK dan jurnal harian kegiatan. } \\
\text { Metode: Diskusi dan tanya jawab. }\end{array}$ \\
\hline
\end{tabular}

\section{Teknik Analisis}

Jenis teknik analisis yang digunakan dalam penelitian ini yaitu analisis tematik yang dilakukan melalui tiga tahap (Creswell, 2008), yaitu pertama, data hasil wawancara yang terkumpul ditranskrip atau dipaparkan secara apa adanya. Dengan metode epoche, pengalaman konseli dideskripsikan untuk menemukan inti dari fenomena yang dialami. Kedua, coding data, yaitu mencari pernyataan-pernyataan yang relevan dengan fokus penelitian. Dalam hal ini, guna mengklasifikasi tema yang muncul, beberapa pernyataan serupa akan dikelompokkan dan kemudian dianalisis dengan literatur yang sesuai. Ketiga, analisis dan penarikan kesimpulan. Untuk menginterpretasi data, dilakukan deskripsi tekstural mengenai apa yang terjadi dan bagaimana fenomena tersebut dialami oleh konseli.

\section{HASIL DAN PEMBAHASAN}

\section{Hasil Penelitian}

Terdapat beberapa tema yang muncul dari hasil wawancara dan konseling dengan kedua orang tua. Berikut dibahas tema yang diberikan pada saat konseling dengan menggunakan pendekatan TSC Framework.

\section{Tema 1: Penolakan Realita Kematian Anak (Tahap Inisial Respon, indikator penolakan)}

a. Respon Ibu

Ibu menyampaikan bahwa pada saat pertama kali mengetahui berita kematian anaknya, ia menolak realita dan terus melakukan pembenaran pada diri bahwa anaknya bersama dirinya masih berada di ruangan persidangan pengadilan terkasus tuduhan "Penyalahgunaan Dana" oleh suaminya, 
"Kalau perasaan sih. saya bilang. saya sampai saat ini merasa anak saya belum mati, Kami masih berada di ruangan persidangan pengadilan. Anak saya hanya saja sedang tertutup matanya karena tidur nyenyak."

b. Respon Ayah

Ayah menyampaikan bahwa pada saat mengetahui kematian anaknya, ia menolak realita dan terus menyalahkan dirinya.

"Saya merasa gagal sebagai Ayah, tidak bisa menjaga kesehatan anak saya. Saya yang membawa anak dan istri saya berada di ruangan pengadilan atas fitnah yang dilontarkan oleh kerabat. Istri dan anak saya pasti terpukul hatinya, tapi bukan bearti Allah merenggut nyawa anak saya."

\section{Membantu Konseli untuk mengidentifikasi Berbagai Persepsi dan Gambaran di dalam}

\section{Sebuah Situasi}

Peneliti berperan sebagai konselor memberikan konseling dan mengkondisikan situasi dimana konseli mengalami pengalaman distress. Hal tersebut ditujukan agar konseli belajar melakukannya sendiri, arahkan konnseli untuk mengisi lembar kerja dimana ia mendeskripsikan situasinya, dan mengidentifikasi perasaan dan reaksi fisik.

Selanjutnya peneliti mengkategorikan skala perasaan dan skala fisik dari 0 sampai dengan 10. Kemudian, peneliti mengarahkan konseli pada situasi sebelum dan sesudah kematian anaknya, dan melihat respon perasaan dan fisik yang muncul dari konseli. Selanjutnya bertukar peran.

\section{Tabel 2. Lembar Kerja TSC Framework}

Lembar Kerja TSC (Diisi Konseli: Ibu)
Situation
Menyatakan situasi bermasalah saya dengan jelas dan ringkas.
Tepatnya, pada tanggal 24 April 2018, saya bersama anak menghadiri persidangan
pengadilan atas tuduhan penyalahgunaan keuangan oleh suami saya. Suasana
ruangan persidangan gaduh saat rekan suami saya terus menyerang suami saya. Anak
saya menangis kencang saat melihat ayahnya dibentak oleh rekannya. Saat itu anak
saya berusia 5 tahun.
Thoughts
Pikiran saya kacau saat berada di persidangan pengadilan tersebut, berbagai pikiran
muncul di situasi tersebut.
"Saya harus kuat menghadapi ini" (menciptakan aturan).
"Saya tidak pernah berhasil menghadapi ketakutan dan kesepian" (menciptakan
persepsi).
"Saya takut tidak mampu menghadapi cobaan hidup" (menciptakan ekspektasi).
Consequences
Apa konsekuensi pikiran-pikiran saya tentang situasi tersebut?
Perasaan dan reaksi fisik saya
Perasaan: sangat cemas dan
Reaksi fisik: keram perut, tidak tidur dengan nyenyak
Komunikasi dan tindakan saya


Dimasa lalu saya menghindari kesepian sejak kematian orang tua

Saya mulai menarik diri dari lingkungan sekitar

(Catatan: Setelah konseli mengisi lembar kerja TSC, kemudian peneliti berperan sebagai konselor memberikan konseling untuk membantu konseli menciptakan persepsi dan gambaran positif terhadap kedukaan yang dialami).

\section{Respon Konselor \\ Situasi Konseli}

"Memang tidak mudah ya berada di dalam situasi tersebut. Tentunya itupun tidak menutup kemungkinan jika pihak lain berada di situasi tersebut mengalami kecemasan tinggi seperti yang Ibu alami. Sebelumnya ibu pernah mengalami situasi yang tidak nyaman dan membuat cemas namun Ibu mampu melewatinya?" (memberikan jeda kepada konseli untuk menjawab dengan tetap menunjukkan penghampiran (attending) yang baik, sehingga tidak terjadinya resistensi terhadap konselor).

\section{Thoughts}

"Beberapa orang mengalami kesulitan dalam mengontrol pikirannya saat dihadapkan kedukaan yang mendalam karena ditinggal kematian orang tercintanya. Bagaimana dengan Ibu sendiri, pikiran apa saja yang muncul saat mengetahui kematian anak Ibu?"

\section{Consequence}

"Saat pikiran-pikiran tersebut muncul, reaksi apa saja yang dialami oleh tubuh maupun perasaan Ibu?"

\section{Pembahasan}

Penelitian ini bertujuan untuk mendalami pengalaman orang tua yang kehilangan anaknya saat persidangan pengadilan. Hasil wawancara dan konseling dengan kedua partisipan memunculkan beberapa tema dalam proses pemaknaan kedukaan. Hasil tersebut menunjukkan bahwa meskipun sudah satu tahun telah berlalu semenjak kematian anak, ayah dan ibu masih mengalami perasaan kehilangan dan reaksi duka.

Seperti yang sudah ditemukan dalam penelitian sebelumnya, situasi terkait penyebab kematian anak membutuhkan penyesuaian diri orang tua, di mana kematian yang tidak terduga berasosiasi dengan reaksi duka yang lebih intens (Lichtenthal, Neimeyer, Currier, Roberts, \& Jordan, 2013; Stroebe et al.,2013; Wijngaards-de Meij et al., 2005). Penyesuaian diri dikarenakan kedukaan kematian dipengaruhi oleh berbagai faktor (Harper, 2004) yaitu: 1) usia orang yang ditinggalkan; 2) pengalaman hidup yang telah dialami oleh orang yang ditinggalkan; 3) jenis kelamin; 4) kepribadian, penyesuaian diri pada orang yang ditinggalkan; 5) latar belakang keluarga dan lingkungan yang ditinggalkan; 6) hubungan antara orang yang ditinggalkan dan orang yang telah tiada; 7) "persiapan" yang dilakukan dalam menghadapi kematian; dan 8) Penyebab kematian tersebut.

Dari kedelapan faktor diatas, terdapat 4 faktor dominan yang dialami oleh orang tua tersebut, yaitu faktor usia, pengalaman hidup yang telah dialami, persiapan yang dilakukan 
dalam menghadapi kematian oleh orang yang ditinggalkan, dan penyebab kematian. Dalam hal ini, Ayah mengalami Inhibited Grief, dimana tidak mampu untuk sepenuhnya membicarakan, menyadari dan mengekspresikan kehilangan yang dialami. Perilaku yang muncul dari Ayah tersebut yaitu seperti kemarahan atau perasaan bersalah yang berlebihan.

Sementara Ibu yang ditinggal kematian anaknya mengalami Unresolved Grief dimana terjadi adanya keluhan fisik maupun psikologis. Ibu mengalami kesulitan bertoleransi dengan hal yang menyakitkan. Hal tersebut tampak terlihat dari keinginan kuat dari Ibu untuk kembali bertemu dengan anaknya yang sudah meninggal. Kondisi tersebut mengakibatkan Ibu mengalami Complicated Grief. Prigerson (2009) menyatakan individu yang tidak menerima ditinggalkan kematian oleh anaknya memiliki resiko yang lebih tinggi untuk mengalami reaksi duka yang kronis (complicated grief).

Gejala complicated grief juga tampak pada diri Ayah, dimana Ayah menggambarkan kedukaannya dengan persaan marah, jengkel, dan dendam. Kondisi Ibu dan Ayah tersebut dialami menggambarkan kedukaan dalam dirinya sebagai perasaan Ibu mengalami kondisi Complicated Grief, karena Gejala tersebut dapat bertahan selama waktu tertentu, mulai dari enam bulan sampai bertahun-tahun. Complicated grief umumnya muncul pada individu yang mengalami kehilangan karena peristiwa kekerasan, di mana kematian tersebut juga tidak terduga (Prigerson et al., 2009). Gejala complicated grief ditemukan pula dalam hasil penelitian ini, di mana Ibu mengalami kesulitan untuk beradaptasi dalam menghadapi kematian anaknya, sedangkan Ayah mendeskripsikan adanya perasaan marah, jengkel, dan dendam yang masih bertahan hingga saat ini.

Seperti yang dikemukakan oleh Kubler-Ross (1970), tahapan kedukaan diawali dengan denial, anger, bargaining, depression, dan acceptance, baik Ibu maupun Ayah mengalami kelima tahapan tersebut. Dengan menggunakan pendekatan TSC Framework, peneliti memberikan sesi konseling dengan 7 sesi. Pikiran-pikiran yang tidak tepat yang persisten dapat memberi tanda bahwa konseli tersebut memiliki banyak aturan yang banyak menuntut. Hal tersebut dapat dilihat bahwa perasaan, reaksi fisik, dan komunikasi yang kurang tepat saling kait mengkait.

Walupun dalam kondisi merasa kehilangan semangat dan harapan, Ayah menguatkan diri untuk bangkit kembali dan melanjutkan hidup untuk menghidupi anak sulungnya yang sedang melanjutkan kuliah di perguruan tinggi. Seperti yang diungkapkan Dyregrov (2016) dalam penelitiannya mengatakan bahwa anak lain di dalam keluarga juga menjadi alasan mendorong orang tua untuk mampu bangkit kembali. Dalam penelitian ini, ayah mengatakan bahwa sampai saat ini ia tidak bisa melupakan kejadian kematian anaknya. Terkait dengan pernyataan tersebut, penelitian lain (Arnold \& Gemma, 2008) mengemukakan bahwa orang tua yang berduka dapat menjadi terbiasa seiring berjalannya waktu, namun tidak akan pernah bisa melupakannya.

Pada kenyataannya, setiap individu memiliki cara berduka masing-masing. Hal tersebut tampak dilihat saat memberikan proses konseling baik kepada Ayah maupun Ibu. Ibu dalam penelitian ini membutuhkan waktu yang lebih lama sebelum akhirnya dapat berfungsi kembali dalam kehidupannya sehari-hari, sedangkan ayah pada penelitian ini dapat 
bangkit kembali dalam waktu tiga bulan setelah kejadian kematian sang anak, meskipun kejadian tersebut banyak memengaruhi produktivitasnya.

Selaras dengan kondisi yang dialami keluarga tersebut, Dyregrov, Dyregrov \& Kristensen (2015) dalam penelitiannya menyatakan bahwa Ibu mengalami reaksi duka yang lebih lama seiring berjalannya waktu dibandingkan dengan Ayah. Oleh karena itu, pemaknaan peristiwa kematian anak seringkali dikaitkan dengan keyakinan bahwa kematian anak mereka merupakan bagian dari rencana Tuhan (Lichtenthal, Neimeyer, Currier, Roberts \& Jordan, 2013). Namun Ayah menyampaikan bahwa dengan melihat kematian anaknya sebagai bagian dari kehendak Tuhan, bukan berarti ia tidak melakukan apa-apa. Melalui pendekatan TSC Framework yang peneliti berikan menghantarkan Ayah dan Ibu tersebut berada di tahap penerimaan diri dan melanjutkan kembali kehidupannya dengan produktif.

\section{SIMPULAN}

Kematian anak menjadi hal yang sulit untuk diterima oleh partisipan, karena kedekatan emosional yang sangat besar. Hasil penelitian menunjukkan bahwa baik Ayah maupun Ibu masih mengalami reaksi duka yang berbeda, Ibu mengalami kondisi Unresolved Grief, sementara Ayah mengalami kondisi Inhibited Grief. Pendekatan TSC yang digunakan untuk mereduksi grief partisipan tampak terlihat hasilnya pada saat partisipan mengalami peralihan kondisi dari tawar menawar (bargain) menuju penerimaan diri. Peneliti menarik kesimpulan bahwa konseli tidak pergi secara otomatis dari situasi ke konsekuensi situasinya, diperlukan keterampilan untuk membangkitkan dan mengkases pikiran untuk mereduksi Grief yaitu dengan menggunakan pendekatan TSC framework (menciptakan aturan, menciptakan persepsi, menciptakan self-talk). Dalam penelitian ini, pendekatan TSC Framework menekankan pada aspek kognitif, rasional dan behavioral tentang kepribadian serta berorientasi pada peningkatan kesadaran sehingga konseli mampu membuat keputusankeputusan dan rencana baru bagi kehidupannya.

Pendekatan TSC Framework merupakan layanan yang diberikan konseli agar mampu menilai kualitas perilakunya sendiri, apakah perilakunya sudah mampu memonitor pikiran dan perasaannya. Program studi Bimbingan Konseling Islam, Fakultas Ushuluddin Adab dan Dakwah, IAIN Syekh Nurjati Cirebon, dapat memperkaya model pendekatan TSC Framework untuk mengembangkan keterampilan monitoring pikiran, perasaan, dan tindakan, yang ditujukan untuk meningkatkan kinerja calon konselor. Pada penelitian ini, objek penelitian terbatas hanya kepada sepasang orang tua yang mengalami duka ditinggal kematian anaknya, sehingga pada penelitian selanjutnya direkomendasikan memperluas objek penelitian pada kelompok orang tua yang mengalami kedukaan ditinggal kematian anaknya.

Metode yang digunakan dalam penelitian ini adalah fenomenologi, yang berfokus pada pemaknaan konseli akan pengalaman ditinggal kematian anaknya. Dengan demikian, pada penelitian selanjutnya direkomendasikan untuk menggunakan metode penelitian R\&D, dimana pengujian metode tidak hanya pada uji coba terbatas, melainkan juga dikembangkan 
pada tahap uji coba yang lebih luas. Asumsi dari uji lebih luas adalah metode yang dihasilkan dapat diterapkan untuk siapapun diluar kelompok uji terbatas. Metode dinilai memiliki tingkat kehandalan yang tinggi dan konsisten, dilihat dari sudut pandang keefektifan antara uji coba terbatas dengan uji coba lebih luas.

\section{DAFTAR PUSTAKA}

Arnold, J. \& Gemma, P. (2008). The Continuing Process of Parental Grief. Death Studies, 32(1), hlm. 658-673.

Creswell, J. W. (2008), Educational Research. New Jersey: Pearson Education.

De Meij et al. (2005). Couple at Risk Following The Death of Their Child: Predictors of Grief Versus Depression. 73(4): hlm. 617-23. DOI:10.1037/002-006X.73.4.617.

Dyregrov, K., Dyregrov, A., \& Kristensen, P. (2015). Traumatic bereavement and terror: The pycchosocial impact on parents and siblings 1.5 years after the July 2011 terror killings in Valentia, S. \& Mansoer, W. W. D. Jurnal Psikologi Ulayat (2019), X(X), XXX-XXX X Norway. Journal of Loss and Trauma, 20(6), hlm. 556-576. DOI: $10.1080 / 15325024.2014 .957603$.

Kübler-Ross, E. (1970). On Death and Dying. London: Taylor and Francis.

Lemme, B. H. (1995). Development in Adulthood. USA: Allyn \& Bacon.

Lichtenthal, W. G., Neimeyer, R. A., Currier, J. M., Roberts, K., \& Jordan, N. (2013). Cause of Death and the Quest for Meaning After the Loss of a Child. Death Studies, 37(4), hlm. 311-342. DOI: 10.1080/07481187.2012.673533.

Maynasari. (2008). Coping Ibu Terhadap Anak. Fakultas Psikologi UIN Syarif Hidayatullah: Jakarta.

Murphy, S. A., Johnson, L. C., Chung, I. J., \& Beaton, R. D. (2003). The Incidence of PTSD Following the Violent Death of a Child and Predictors of Change Over Time. Journal of Traumatic Stress, 16(1), hlm. 17-26.

Papalia, E. D. et al. (2008). Human Development (Perkembangan Manusia). Jakarta: Salemba Humanika.

Prigerson, H. G., Horowitz, M. J., Jacobs, S.C., Parkes, C. M., Aslan, M., Goodkin, K., Maciejewski, P. K. (2009). Prolonged grief disorder: Psychometric validation of criteria proposed for DSM-V and ICD-11. PLoS Medicine, 6(8). doi: 10.1371/journal.pmed.1000121.

Nelson-Jones, R. (2012). Pengantar Keterampilan Konseling. Pusataka Pelajar: Yogyakarta.

Santrock, J. W. (2004). Life-Span Development. Jakarta: Erlangga.

Weiten, W., Dunn, D. S., \& Hammer, E.Y. (2019). Psychology Applied to Modern Life: Adjusment in the 21st Century (11th ed.). Stamford, CT: Cengage Learning. 
48 | Novianti - Pendekatan Thought Situation ... 